\title{
Avian Wound Myiasis Caused by Calliphora vicina Robineau - Desvoidy (Diptera: Calliphoridae) in an Immature Migrating Eastern Imperial Eagle (Aquila Heliaca Savigny) (Aves: Accipitridae) in Southwestern Iran
}

\author{
Mehrdad Parchami-Araghi ${ }^{1 *}$, Farshad Eskandari ${ }^{2}$ and Ebrahim Gilasian ${ }^{1}$ \\ ${ }^{1}$ Insect Taxonomy Research Department, Iranian Research Institute of Plant Protection, Tehran 19395-1454, Iran \\ 'Islamic Azad University, Khuzestan Science and Research Branch, Ahvaz, Iran
}

\begin{abstract}
We captured an injured immature Eastern Imperial Eagle (Aquila heliaca Savigny) on the outskirts of the city of Alvan (south of city of Shoush) in the Iranian southwestern province of Khuzestan in February 2014. The young bird had been leg-ringed at the nestling stage in Kazakhstan in June 2013 before setting off on its migration towards southern parts of Iran. The eaglet was suffering from a deep fracture in its left wing leading to an extensive necrotic wound, which was heavily infested by maggots (fly larvae). The examination of internal cephalopharyngeal skeleton and external morphological characters of the third-instar larvae, including posterior spiracles, led to the identification of the blow fly species of Calliphora vicina Robineau-Desvoidy. This is the first report of myiasis in a vulnerable wild bird species in Iran and the first recorded infestation of an Eastern Imperial Eagle by the facultative myiasis agent C. vicina in the world.
\end{abstract}

Keywords: Avian traumatic myiasis; Raptors; Blow flies; Veterinary parasitology; Ornithology

\section{Introduction}

Myiasis is a term that describes the infestation of living animals by fly larvae. A specific type of myiasis in the nestlings of wild birds is caused by the blood-sucking larvae of different genera including Protocalliphora (Calliphoridae), which are commonly known as Bird Blow Flies [1-4]. Wild birds are also susceptible to obligatory (primary) and facultative (secondary) wound myiases. The southern part of Iran is the home of two important obligatory parasites the Old World screw-worm fly Chrysomya bezziana (Calliphoridae) and the flesh fly Wohlfahrtia magnifica (Sarcophagidae) as well as a number of facultative ectoparasites such as C. albiceps, C. megacephala, C. rufifacies, C. regalis, W. nuba, Lucilia spp. and Calliphora spp. [5,6] The available records of wound myiasis in wild birds are primarily related to the facultative parasitic species in the calliphorid genera of Lucilia and Calliphora [7-10] as well as sarcophagid species of $W$. vigil [11] and $W$. opaca [12]. The only available case of avian obligatory wound myiasis has been associated with the species W. magnifica in Greylag goose (Anser anser) [13]. Although the records of wound myiasis in the birds of prey are scarce, a few cases have been reported in falcons [8] and also in a Eurasian Eagle Owl in Iran [14]. The Eastern Imperial Eagle (Aquila heliaca) has been declared a vulnerable species with declining populations since 2012 [15]. The southwestern province of Khuzestan, with extensive marshes and the Persian Gulf province of Hormozgan, including the Qeshm Island and Hara Protected Area, have long served as important wintering areas for the migrating $A$. heliaca $[16,17]$ though prolonged drought and habitat destructions have taken their toll on the numbers of the birds.

\section{Materials and Methods}

The young bird had been ringed in its breeding site in Aktobe region, Kazakhstan (R. H. Bekmansurov pers. comm.) coded "AK-1013-1M" (Figure 1A). We removed a sizeable amount of the larvae from the necrotic tissues of the wing and put them in the vials containing $75 \%$ ethyl alcohol. Due to the severity of the damage, we had to amputate the wing from the elbow afterward. In order to examine the internal structures of the larvae, we placed them into a saturated solution of absolute alcohol and phenol in accordance with the clearing method of larvae by Craig Turner, [18]. After 24 hours, the structures were visible

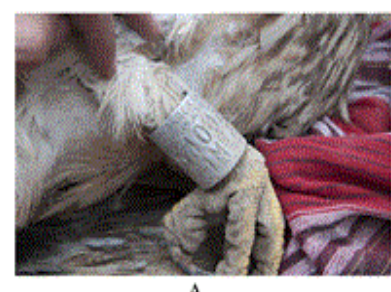

A

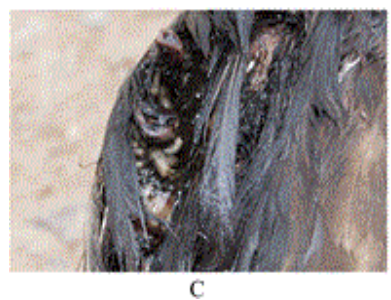

C

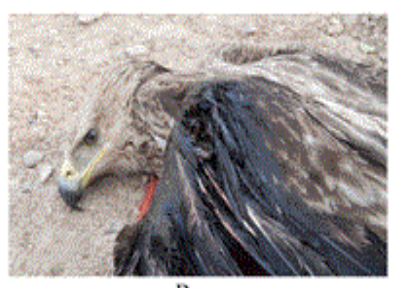

B

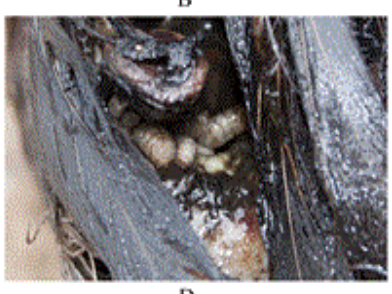

D
Figure 1: The injured Eastern Imperial Eagle, Aquila heliaca, in the province of Khuzestan, Iran, February 17, 2014. (A) the ring attached to the leg; (B) broken left wing and decayed wound; (C-D) maggots of $C$. vicina feeding on the necrotic tissues of the wound.

*Corresponding author: Araghi MP, Insect Taxonomy Research Department, Iranian Research Institute of Plant Protection, Tehran 19395-1454, Iran, Tel: +982122403012 ext. 7215; E-mail: maraghi20@yahoo.ca

Received November 01, 2014; Accepted December 29, 2014; Published December 30, 2014

Citation: Araghi MP, Eskandari F, Gilasian E (2015) Avian Wound Myiasis Caused by Calliphora vicina Robineau-Desvoidy (Diptera: Calliphoridae) in an Immature Migrating Eastern Imperial Eagle (Aquila Heliaca Savigny) (Aves: Accipitridae) in Southwestern Iran. J Veterinar Sci Technol 6: 212. doi:10.4172/2157-7579.1000212

Copyright: @ 2015 Araghi MP, et al. This is an open-access article distributed under the terms of the Creative Commons Attribution License, which permits unrestricted use, distribution, and reproduction in any medium, provided the original author and source are credited. 
Citation: Araghi MP, Eskandari F, Gilasian E (2015) Avian Wound Myiasis Caused by Calliphora vicina Robineau-Desvoidy (Diptera: Calliphoridae) in an Immature Migrating Eastern Imperial Eagle (Aquila Heliaca Savigny) (Aves: Accipitridae) in Southwestern Iran. J Veterinar Sci Technol 6: 212. doi:10.4172/2157-7579.1000212

for examination. The identification of the species was made possible by the keys to the calliphorid genera and larval stages of Calliphora species written by [19-21]. We used AM423X DinoEye digital eyepiece for taking photographs of the structures of the larvae. Drs Pascal Eckhoff (Museum für Naturkunde, Berlin, Germany) and Rinur H. Bekmansurov (Russian Raptor Research and Conservation Network) helped with the identification of the eagle species.

\section{Results and Discussion}

We found the immature Eastern Imperial Eagle A. heliaca helplessly grounded (Figure 1B) suffering from a severe fracture and decayed wound in the left wing, while a large number of fly larvae were feeding on the necrotic tissues (Figure 1C and 1D). The capture of the bird took place on the vicinity of the city of Alvan (N31 ${ }^{\circ} 56^{\prime} 34.56^{\prime \prime}$ E48 $\left.21^{\prime} 15.87^{\prime \prime}\right)$ in the Khuzestan province of Iran on February 17, 2014 (Figure 2). We examined the taxonomically important structures of the third-instar larvae, including the internal cephalopharyngeal skeleton (Figure 3A), anterior spiracle and pleural spines on the first thoracic segment (Figure 3B) plus posterior spiracles (Figure 3C) and identified the species of the larvae as Calliphora vicina. This is the first record of myiasis in a vulnerable wild bird species in Iran and the first reported case of the wound myiasis in A. heliaca in the world. C. vicina is known as a facultative (secondary) myiasis agent and synanthropic species whose adults usually frequent the urban areas affected with poor sanitation. The adult female lays her eggs in decomposing organic matter, excrements, carrion or dead tissues of the wound of living animals to hatch to worm-like larvae. While feeding on the substrate, the larvae go through three developmental changes (instars) and finally the third-instar larvae fall to the ground to pupate. Depending on the temperature, the pupal stage takes from several days to a few weeks and eventually the adult flies push their way out of the puparia.

The shape of the fracture strongly indicated that the bird had collided with a physical barrier such as a transmission tower or a building when approaching the built-up areas. The presence of $C$. vicina

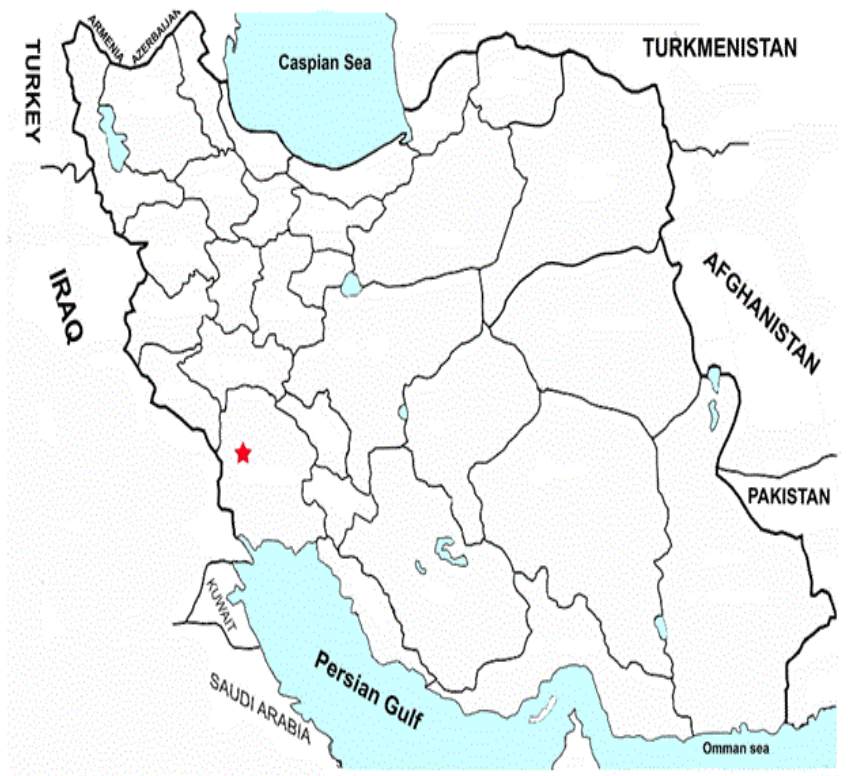

Figure 2: The location of the injured Eastern Imperial Eagle A. heliaca, province of Khuzestan, Iran.

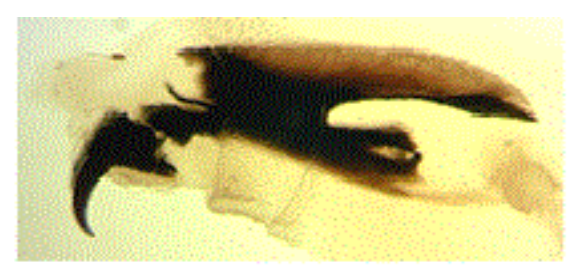

A

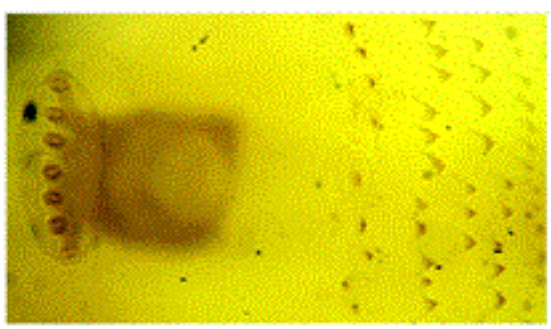

B

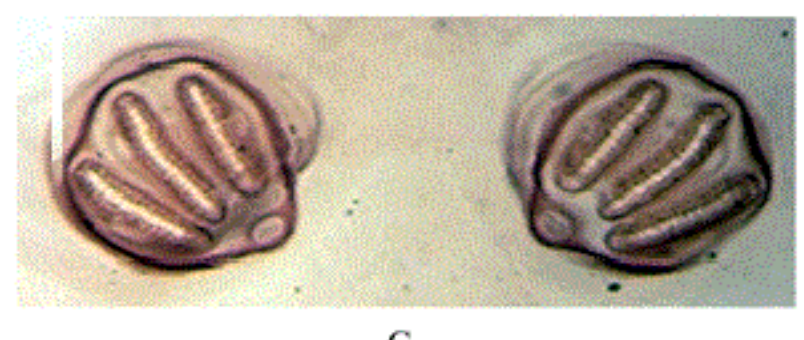

C

Figure 3: The taxonomically important structures of the third-instar larva of C. vicina. (A) cephalopharyngeal skeleton; (B) anterior spiracle and pleural spines on the first thoracic segment; (C) posterior spiracles.

larvae suggested that the bird had suffered its injuries in provinces with temperate climates before entering the warmer and lower elevation areas of Khuzestan, where is the home of the aggressive Ch. bezziana and $W$. magnifica. These two species often precipitate the myiasis in this area by attacking the living tissues of the wound, before it turns rotten, leaving no space for other saprophagous flies such as C. vicina to incur myiasis.

\section{Conclusion}

Over the past three decades, the southern areas of Iran have experienced enormous environmental pressures due to man-caused habitat destructions from the 8-year Iran-Iraq war, deforestation, taking lands for agricultural use and erecting dams leading to drying up of rivers and wetlands. Also, illegal activities, including poaching of wildlife, especially the birds of prey and smuggling them into the neighboring Arab states on the Persian Gulf coast has been a common occurrence in the areas affected by poor economy and mismanagement. The sprawling cities and continuous alterations in their countryside, high rises, power lines, transmission towers, fences and barbed wires are also responsible for the deaths of many migrating birds in Iran. As part of the documentation of Iranian biodiversity, we have launched a joint project with the Iranian Department of Environment to study the Diptera fauna of domestic wetlands and national parks. To date we have collected thousands of fly specimens associated with wildlife, using specially designed traps. 
Citation: Araghi MP, Eskandari F, Gilasian E (2015) Avian Wound Myiasis Caused by Calliphora vicina Robineau-Desvoidy (Diptera: Calliphoridae) in an Immature Migrating Eastern Imperial Eagle (Aquila Heliaca Savigny) (Aves: Accipitridae) in Southwestern Iran. J Veterinar Sci Technol 6: 212. doi:10.4172/2157-7579.1000212

Since full recovery from its wound, the flightless eagle has been cared at the Karkheh National Park, Khuzestan, Iran.

\section{Acknowledgements}

We are grateful to Drs P. Eckhoff (ZMHB) and R. H. Bekmansurov (RRRCN) for identifying the species of the eaglet. We also appreciate the cooperation of the rangers of the Karkheh National Park in the course of this study.

\section{References}

1. Little SE (2009) Myiasis in Wild Birds. Parasitic Diseases of Wild Birds (ed. by Atkinson CT, Thomas NJ, Hunter DB). Wiley-Blackwell, Oxford 546-556.

2. Parchami-Araghi M, Peris SV, Gonzalez-Mora D (2001) New records of Iranian Calliphoridae and Sarcophagidae, with a guide to the males of Palaearctic Protocalliphora (Diptera: Calyptratae). Bulletin of the Royal Spanish Society of Natural History ( Section Biological ) 96: 175-181.

3. Sabrosky CW, Bennett GF, Whitworth TL (1989) Bird Blow Flies (Protocalliphora) in North America (Diptera: Calliphoridae) with notes on the Palearctic species. Smithsonian Institute Press, Washington, D.C

4. Zumpt F (1965) Myiasis in Man and Animals in the Old World. Butterworths and Co., Ltd., London.

5. Parchami-Araghi M (1995) The blow flies of the subfamily Chrysomyinae (Diptera: Calliphoridae) in Iran. Journal of Entomological Society of Iran 15: $27-44$

6. Parchami-Araghi M (2013) First report of fatal wound myiasis caused by Chrysomya bezziana (Dip.: Calliphoridae) in Persian Fallow Deer populations in Iran. Fly Times 51: 9-13

7. Baumgartner DL (1988) Review of myiasis (Insecta: Diptera: Calliphoridae, Sarcophagidae) of Nearctic wildlife. Wildlife Rehabilitation 7: 3-46.

8. Cooper JE (1978) Veterinary aspects of Captive Birds of Prey. Standfast Press, Gloucestershire, UK

9. Hinaidy HK, Frey H (1982) Facultative myiasis in wild-living animals as result of injuries. Communications of the Society for Tropical Medicine and Osterrelschischen Parasitologia. 4: 85-90.
10. Hinaidy HK, Frey $\mathrm{H}$ (1984) Further cases of facultative myiasis in vertebrates in Austria. Wiener Tierarztliche Monatsschrift 71: 237-238.

11. Eschele JL, Defoliart GR (1965) Rearing and biology of Wohlfahrtia vigil (Diptera: Sarcophagidae). Annals of the Entomological Society of America 58: 849-855.

12. Wobeser G, Gajadhar A, Beyersbergen GW, Sugden LG (1981) Myiasis by Wohlfahrtia opaca (Coq.): A cause of mortality of newly hatched wild ducklings. Canadian Field Naturalist 95: 471-473.

13. Farkas R, Szanto Z, Hall M (2001) Traumatic myiasis of geese in Hungary. Veterinary Parasitology 95(1): 45-52.

14. Pirali-Kheirabadi K, Cheraghchi-Bashi M, Navidpour S (2010) Infestation of an owl (Bubo Bubo) with Lucilia spp. Comparative Clinical Pathology 19: 221-224.

15. Galushin V, Hallmann B, Horváth M, Katzner T, Kovács A, et al. (2013) Aquila heliaca. The IUCN Red List of Threatened Species. Version 2014.2. (BirdLife International).

16. Hamidi N, Musavi SB (2006) Status of Imperial Eagle Aquila heliaca and Greater Spotted Eagle Aquila clanga in Hormozgan Province, southern Iran. Podoces 1: 67-70.

17. Scott DA (2001) The birds of Shadegan marshes and adjacent tidal mudflats Islamic Republic of Iran: the result of surveys carried out by the Ornithology Unit of the Department of the Environment in the 1970s).

18. Craig Turner Jr E (1990) Method of clearing Diptera larvae for examination of internal structures. Journal of Agricultural Entomology 7: 217-219.

19. Holloway BA (1991) Identification of third-instar larvae of flystrike and carrionassociated blow flies in New Zealand (Diptera: Calliphoridae). New Zealand Entomologist 14: 24-28.

20. Wallman JF (2001) Third-instar larvae of common carrion-breeding blowflies of the genus Calliphora (Diptera: Calliphoridae) in South Australia. Invertebrate Taxonomy 15: 37-51.

21. Szpila K (2010) Key for the identification of third instars of European and Mediterranean blowflies (Diptera, Calliphoridae) of forensic importance. Current concepts in forensic entomology (ed. by Amendt J, Campobasso CP, Goff ML, Grassberger M), pp. 43-56. Springer, Dordrecht, Heidelberg, London, New York. 